\title{
ASSESSMENT OF THE RELIABILITY OF COGNITIVE (ATTENTION AND MEMORY) TESTS
}

\author{
Vaida Berneckè ${ }^{1,2}$, Nerijus Eimantas ${ }^{2}$, Henrikas Paulauskas², Beata Skaisgirytè ${ }^{2}$, \\ Justas Kudrevičius ${ }^{2}$, Marius Brazaitis ${ }^{2}$ \\ Šiauliai State College ${ }^{1}$, Šiauliai, Lithuania \\ Lithuanian Academy of Physical Education'2, Kaunas, Lithuania
}

\begin{abstract}
Research background and hypothesis. Special neuropsychological tests, which are used to assess cognitive functions in clinical practice, are often complicated, time-consuming, demanding special knowledge and expensive; therefore, cognitive functions frequently remain insufficiently assessed. For this reason, our selected and validated tests intended for the assessment of short-term memory and attention could be successfully applied in sports and clinical rehabilitation.

Research aim. The aim of this study was to assess the reliability of the tests of cognitive functions (memory and attention).

Research methods. The reliability of the tests was assessed using the intraclass correlation coefficient (ICC) and variation coefficient $(V C)$. Young and healthy students $(n=41)$, aged from 18 to 30 (24.6 \pm 2.3$)$, participated in the research. The participants accomplished the tests 4 times, i. e. 2 times (with a one-hour break) on the first day (teaching) and 2 times (with a one-hour break) on the second day (reliability testing).

Research results. The results of testing the volume of spatial memory and even number recognition ranged from high to very high reliability of the tests. The results of ICC single of testing memory for figure recognition demonstrated low reliability, whereas ICC average proved average reliability. The results of complex reaction assessment, search for image samples and attention transfer ranged from high to a very high reliability of the tests.

Discussion and conclusions. The reliability of the tests of memory and attention assessment is high (with the exception of figure recognition tests, the reliability of which is average/low); therefore, the tests are suitable to be used in sport and clinical rehabilitation practice, aiming at determining the changes in cognitive functions under the influence of external factors, e. g. cold, heat, etc.
\end{abstract}

Keywords: brain functions, validity, stability, testing.

\section{INTRODUCTION}

$\mathrm{T}$ he most frequently used tool of exploring the reliability of tests is their re-testing. The stability of re-testing is assessed by repetitive testing of the same respondents after a certain amount of time (Liu et al., 2010). The reliability of re-testing is based on the correlation of two (or more) experiments. Provided the tests are compiled in the right way, their results should be similar after re-testing. The validity of the test defines whether the research method really measures what it is supposed to measure, and whether the test results are correct (Gur et al., 2010). The main principles of compiling the methodology of memory and attention assessment have undergone only minor changes since the times of H. Ebbinghaus (1885/1962) and G. A. Miller (1955); these methodologies are based on the wellknown principles of the research of memorization and attention processes. The tasks, which are applied for the assessment of attention and memory processes, are frequently included into the composition of more complex research, e. g. 
Wechsler Adult Intelligence Scale (WAIS) (Kramer et al., 2011). Therefore, these tests do not demand additional proof for their reliability.

Depending on the specificity of the task (attention or memory), a cognitive test indirectly points to separate functions of chief nerve centers and are intensively applied in the fields of medicine, sports and psychology (Collie et al., 2003). Attention helps to distinguish a separate item from the group clearly and assuredly. An adult person can focus his/her attention on 4 to 6 independent objects (Martens et al., 2010). The frontal lobe of the brain determines concentration of attention, integrates the awareness and understanding of all the components of information, as well as organizes the processing of information data. The pre-frontal lobe controls alertness as well as the states of attention and activeness (Chein, Fiez, 2010). The duration of reaction (indirectly) shows the speed of "calculation" performed by the brain. It has been determined that when a choice has to be made, the processes in the central nerve system slow down (Skurvydas, 2011). The frontal part of cerebral cortex is responsible for the action plan (Correani, Humphreys, 2011), whereas thalamus is responsible for understanding, and the frontal nuclei of the thalamus regulate memorization of new information. The complex functions of cognition and analysis are formed in the parietal lobe of cerebral cortex (Min, 2010).

Memory is one the most important and main functions of the brain. From the temporal point of view, memory consists of three stages: sensory $(0.1-0.5 \mathrm{~s}$ ), short-term (up to $20 \mathrm{~s}$ ), and long-term (information is stored for unlimited time) (Axmacher et al., 2009). One of the most significant components of any cognitive activity is short-term storage of information and its management in memory. Short term memory is located in the cerebral cortex (Thoresen et al., 2011). According to the type of memorization, longterm memory is divided into episodic (for personal experience), semantic (for general knowledge) and procedural (intended for skills). Hyppocampus and hypothalamus are responsible for episodic and semantic memory. Hippocampus is also responsible for working memory, whereas the chief nerve ganglion and cerebellum - for procedural memory (Correani, Humphreys, 2011). In shortterm (operational, working) memory important data from sensory organs and long-term memory are fixed for a short time and promptly rearranged.
Working memory, also referred to as operational, is defined as a system, which temporarily stores and manages the necessary information to accomplish complex cognitive tasks, such as learning, reasoning and understanding (Eng et al., 2005). In other words, working memory is needed so that we could operate in the surrounding world, whereas short-term and long-term memories ensure that we use the obtained information (Morey, Cowan, 2005). Working memory is very short, it lasts from several seconds to a few dozens of seconds (Axmacher et al., 2009). Depending on the sensory organs, which were used to obtain information, four types of memory are distinguished: motor (memory of movements), emotional, visual, and verbal-logical (verbal) (Mizuno, Takeda, 2009).

In this research the reliability of cognitive tests has been assessed using intraclass correlation coefficient (ICC), which is widely applied in the assessment of the correlation of re-tests. This method assesses not only the interdependence between two variables, but also the compatibility of these two variables in terms of their average mean (Friedman et al., 2008; Singh et al., 2011). There are two possible ways of the assessment of ICC: reliability of single assessments (ICC single), when the data of individual experts is analyzed; and reliability of assessment averages (ICC average), which covers the analysis of the average mean of experts' data. Besides, variation coefficient $(V C)$ has also been applied, which shows the percentage of the average deviation from the mean. The drawback of cognitive tests lies in the alterations of the results, obtained in different populations; the result may also be affected by such factors as age (Stein et al., 2010), education, disease, e. g. cerebrum distemperantia, etc. (Gur et al., 2010); therefore, the reliability of tests should be assessed individually for a particular population in particular circumstances. It is also important to determine whether the interaction, the researcher and the research participants are reliable (Skurvydas et al., 2011).

The aim of the research is to assess the reliability of tests of cognitive functions (memory and attention).

Organization and Procedure of the Research. The research was conducted in the laboratory of The Centre of Fundamental and Clinical Research in Movement at the Lithuanian Academy of Physical Education. The research participants were introduced to the aims, procedure and possible 
inconveniences of the research. Young and healthy students of the Lithuanian Academy of Physical Education ( $\mathrm{n}=14)$, aged from 18 to $30(24.6 \pm 2.3)$, participated in the research. They accomplished the tests four times, i. e. two times (with an hour's break) on the first day (teaching) and two times (with one hour's break) on the second day (retesting to assess the reliability). There was a 24hour break between the first and the second day's testing. The research participants had to complete six tests (three tests for memory and three for attention), the tests were presented in random order. The accomplishment of all tests lasted approximately for 20 minutes. The participants completed the tests in a quiet environment: they were not disturbed by other people, noise, music or other distracters.

\section{RESEARCH METHODS}

Memory assessment. Memory tests are used to assess the stages of short-term memory: memorization, storage and recall (Morey, Cowan, 2005). To assess the above-mentioned peculiarities, three standard memory tests were selected (Collie et al., 2003), which helped to assess the volume of spatial memory, as well as recognition of even numbers and figures.

The volume of spatial memory was assessed using "the test of memorizing the quantity of numbers". The test is based on G. A. Miller's (1955) standardized norm applied for short-term memory, stating that a person is able to memorize $7 \pm 2$ symbols in three seconds or a very short time (up to 20 seconds). To test spatial memory, research participants had to memorize a sequence of numbers; after memorizing it, they had to enter it on the computer. The following line of numbers appeared only after the participant got ready (Figure 1 (a)). The duration of showing the numbers on the monitor (in our case a sequence of numbers) is very important in such kind of tests. Since the demonstrated numbers are not complex objects, an interval of $3000 \mathrm{~ms}$ was chosen. If a research participant forgot one or several numbers, $\mathrm{s} /$ he had to enter only those numbers that $\mathrm{s} / \mathrm{he}$ had memorized; they should not have entered invented numbers. The first line of numbers consisted of 7 numbers. If the participant memorized and entered the right sequence of numbers, the following one should consist of 8 numbers. If $\mathrm{s} /$ he made a mistake, the next task contained 6 numbers. In case the participant made another mistake, the following line would consist of 5 numbers and so on. Sixteen numeric lines were presented for the participants. The results of the test reflect the average length of the memorized sequence of numbers, i. e. the quantity of numbers constituting the sequence and the average of recognized numbers.

During the assessment of memory for equal number recognition, the participants were given a sequence of even numbers on their screens. They had to memorize 10 even numbers, and after their disappearance, enter them into the empty spaces on the computer in random order (Figure 1 (b)). The research included two sequences of ten numbers. The results of the test depended on the number of correct answers of both attempts (maximum 20).

The test of the assessment of memory for figure recognition was based on the research results conducted by J. H. Song and Y. Yang (2006). They proved that visual working memory is able to memorize 3 colors, 2 shapes of objects and 2 objects in terms of their color and shape. Only a few features can be memorized at a time. Despite that we can memorize 4 basic features (e. g. color), we can memorize only 2 complex features (e. g. a random form). In terms of the duration of information storage, short-term memory lasts only up to 20 seconds (Endestad, 2011); therefore, the figures on the monitor were displayed for 15 seconds so that we could avoid the transfer of information into long-term memory. While identifying the quantity of visual memory, a participant was shown 9 different geometrical shapes at a time, which they had to memorize in 15 seconds (Figure 1 (c)). After the picture had vanished, there appeared a table with 28 different figures, including the ones to memorize. The result of our test for the memorization and recall of geometrical shapes depended on the number of correctly recognized figures (the maximum possible assessment was 9).

Attention assessment. Testing of attention allows investigating the main characteristics of attention: stability, concentration, distribution and transfer (Correani, Humphreys, 2011). The research of the mentioned peculiarities included the following tests: assessment of complex reaction, search for visual objects and tests of attention transfer.

Test for the assessment of complex reaction is intended to determine the speed of the choice of correct response in a given situation, when a person needs to choose one of the two possible responses to 


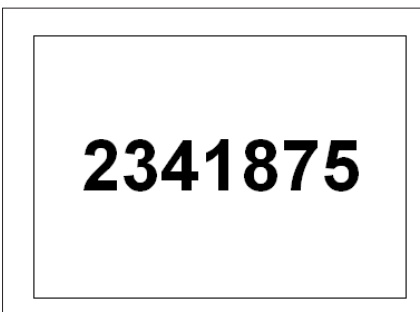

a)

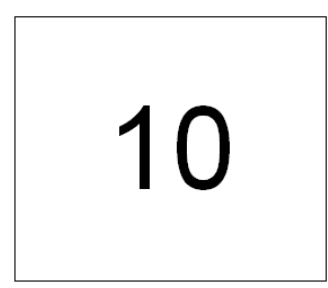

b)

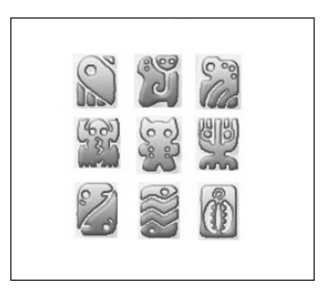

c)

Figure 1. Tests for the assessment of memory characteristics

Note. a) test for the volume of special memory, b) test for even number recognition, c) test for figure recognition.

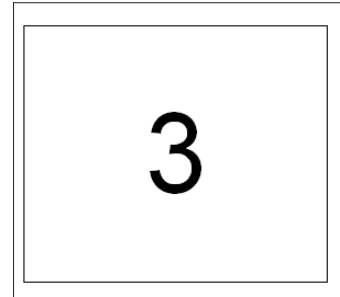

a)

\begin{tabular}{|c|c|c|c|c|}
\hline 9 & 2 & 12 & 13 & 4 \\
\hline 1 & 14 & 17 & 6 & 19 \\
\hline 10 & 3 & 18 & 22 & 23 \\
\hline 15 & 16 & 5 & 24 & 7 \\
\hline 8 & 11 & 20 & 25 & 21 \\
\hline
\end{tabular}

b) \begin{tabular}{|c|c|c|c|c|c|c|}
\hline 9 & 15 & 9 & 12 & 16 & 3 & 10 \\
\hline 24 & 23 & 1 & 19 & 15 & 8 & 17 \\
\hline 18 & 14 & 13 & 6 & 2 & 10 & 25 \\
\hline 11 & 2 & 24 & 23 & 5 & 12 & 24 \\
\hline 20 & 17 & 11 & 22 & 19 & 3 & 13 \\
\hline 7 & 16 & 6 & 22 & 14 & 8 & 4 \\
\hline 7 & 1 & 20 & 4 & 5 & 18 & 21 \\
\hline
\end{tabular}

c)
Figure 2. Tests for attention assessment a stimulus as fast as possible (Kubicki et al., 2012). While accomplishing the test for complex reaction assessment, the research participant had to press the right arrow $(\rightarrow)$ as quickly as possible when an even number appeared on the computer screen, and press the left arrow $(\leftarrow)$ when an odd number appeared (Figure 2 (a)). While accomplishing the test, attention was focused on one visual field area. The time span between the emergence of numbers (the span between the last pressing of the button and appearance of the next number) shifted from 0.5 to 3 seconds. The variation in time was necessary that the participant would not know when to expect the next number. The duration of the test was 3 minutes, the result depended on the latent period of the responses (the time between the appearance of a number on the screen and pressing on the arrow), the number of responses and the number of correct answers.

The test for the search of visual objects was intended to assess the distribution of attention, i.e. the ability to accomplish several actions at a time (Kastner et al., 1999). A participant was provided with a matrix of 25 boxes, which listed the numbers from 1 to 25 in random order (Figure 2 (b)). Using the mouse, the participants had to find and order the right sequence of numbers as quickly as possible. The result depended on the average time of accomplishing five tasks.

The test for attention transfer was intended for the investigation of attention concentration and sustention as well as the speed of information processing (Martens et al., 2010). The essence of this test was a purposeful transfer of attention from one object to another. The research participant was presented with a matrix of 25 hollow and 24 solid numbers (Figure 2 (c)). The participants had to arrange the hollow numbers in the increasing order from 1 to 25 , and solid numbers in the decreasing order from 24 to 1 . Using the computer mouse, the numbers were ordered in the following sequence: $1-\mathrm{a}$ hollow number, $24-\mathrm{a}$ solid number, $2-\mathrm{a}$ hollow number, 23 - a solid number, etc. The sum of the hollow and solid numbers should always equal to $25(1+24=25,2+23=25$, etc. $)$. The duration of the test was 5 minutes. The result reflected the speed of the accomplishment of the task, which ranged from 0 to 300 seconds.

The reliability of research results was assessed by calculating the average of the population, standard deviation, and intraclass correlation coefficient (ICC), which shows the correlation of re-testing (Singh et al., 2011) and coefficient of variation $(C V)$, which shows the variation of the characteristics of different compared totalities. The lower the coefficient of variation, the lower the variation of the characteristics, and vice versa. This is a percentage proportion of the average square deviation and the mean. It is claimed that if the significance of the coefficient of variation is lower than $10 \%$, it shows a high stability of the results between the two characteristics (Sutton et al., 2002). The assessment of ICC: if it ranges from 1.00 to 0.90 , the correlation is very high; from 0.89 to 0.70 - the correlation is high; from 0.69 to 0.50 the correlation is average; from 0.49 to 0.26 - the 
correlation is low; and $<0.26$ shows low correlation. The statistical significance is $\mathrm{p}<0.05$ (Aarrestad et al., 2004). The reliability was assessed using the program SPSS 12.0.1 for Windows.

\section{RESEARCH RESULTS}

Results of assessment reliability of memory Tests. The data averages and intraclass correlation coefficient of the two memory tests (the test and retest) are presented in Table 1.

The results of the average length of number sequence in testing the volume of spatial memory showed high reiteration of the results of both tests (the test and re-test). The results of the reliability of single assessments (ICC single) and reliability of assessment averages (ICC average) revealed a high and very high reliability of the test (significant at $\mathrm{p}<0.001)$. Variation coefficient $(1.32 \%)$ disclosed a very high stability and minimal variation between the test and re-test results. The results of the intraclass correlation coefficient and variation coefficient $(2.22 \%)$ of the average number of guessed symbols of testing the amount of numbers memorization also revealed a very high reliability of test results (significant at $\mathrm{p}<0.001$ ).

The results of single assessment reliability (ICC single) and assessment averages reliability (ICC average) of testing even number recognition proved a very high reliability of the test (significant at $\mathrm{p}<0.0001$ ) (Table 1). The coefficient of the afore-mentioned test $(1.56 \%)$ showed a very high stability and minimal variation between the test and re-test results.

The results of single assessment reliability (ICC single) of testing memory for figure recognition demonstrated low reliability, whereas the results of assessment averages reliability (ICC average) proved average reliability of the test (significant at $\mathrm{p}<0.01$ ) (Table 1). However, the variation coefficient of the test (4.73\%) showed high stability between test results.

Results of assessment reliability of attention tests. The data averages and intraclass correlation coefficient of the two attention tests (the test and re-test) are presented in Table 2.

The results of the test of complex reaction assessment revealed a high reliability of single ICC assessments and a very high reliability of ICC

Table 1. Results of the assessment of the reliability of memory tests

\begin{tabular}{|c|c|c|c|c|c|c|c|c|}
\hline \multirow{3}{*}{ Criterion } & \multicolumn{4}{|c|}{ Volume of spatial memory } & \multirow{2}{*}{\multicolumn{2}{|c|}{\begin{tabular}{|c|}
$\begin{array}{c}\text { Memory for even number } \\
\text { recognition }\end{array}$ \\
$\begin{array}{c}\text { Number of correct } \\
\text { answers }\end{array}$ \\
\end{tabular}}} & \multirow{2}{*}{\multicolumn{2}{|c|}{$\begin{array}{c}\begin{array}{c}\text { Memory for figure } \\
\text { recognition }\end{array} \\
\text { Number of correctly } \\
\text { recognized figures } \\
\end{array}$}} \\
\hline & \multicolumn{2}{|c|}{$\begin{array}{c}\text { Average length of numeric } \\
\text { sequence }\end{array}$} & \multicolumn{2}{|c|}{$\begin{array}{c}\text { Average number of } \\
\text { guessed symbols }\end{array}$} & & & & \\
\hline & Test & Re-test & Test & Re-test & Test & Re-test & Test & Re-test \\
\hline $\begin{array}{c}\text { The average mean } \\
\text { and SD }\end{array}$ & $6.6 \pm 0.69$ & $6.69 \pm 0.71$ & $6.22 \pm 0.86$ & $6.36 \pm 0.80$ & $9.39 \pm 2.50$ & $9.54 \pm 2.18$ & $7.22 \pm 1.19$ & $6.88 \pm 1.42$ \\
\hline ICC (single) & \multicolumn{2}{|c|}{$0.82 * *$} & \multicolumn{2}{|c|}{$0.86 * *$} & \multicolumn{2}{|c|}{$0.68 * * *$} & \multicolumn{2}{|c|}{$0.36^{*}$} \\
\hline ICC (average) & \multicolumn{2}{|c|}{$0.90 * *$} & \multicolumn{2}{|c|}{$0.93 * *$} & \multicolumn{2}{|c|}{$0.81 * * *$} & \multicolumn{2}{|c|}{$0.53 *$} \\
\hline
\end{tabular}

Note. SD - standard deviation; ICC (single) - reliability of single assessments of intraclass correlation coefficient; (average) - reliability of assessment averages of intraclass correlation coefficient; ${ }^{*}-\mathrm{p}<0.01 ; * *-\mathrm{p}<0.001 ; * * *-\mathrm{p}<0.0001$.

Table 2. Results of the assessment of the reliability of attention tests

\begin{tabular}{|c|c|c|c|c|c|c|}
\hline \multirow{3}{*}{ Criterion } & \multicolumn{2}{|c|}{ Test of complex reaction } & \multicolumn{2}{|c|}{ Test of search for image samples } & \multicolumn{2}{|c|}{ Test for attention transfer } \\
\hline & \multicolumn{2}{|c|}{ Time of reaction, $\mathrm{ms}$} & \multicolumn{2}{|c|}{$\begin{array}{l}\text { Average time of the } \\
\text { accomplishment of five tasks, s }\end{array}$} & \multicolumn{2}{|c|}{$\begin{array}{c}\text { Speed of accomplishing } \\
\text { the task, ms }\end{array}$} \\
\hline & Test & Re-test & Test & Re-test & Test & Re-test \\
\hline $\begin{array}{c}\text { Average mean and } \\
\text { SD }\end{array}$ & $662.54 \pm 95.43$ & $642.34 \pm 78.52$ & $39.98 \pm 8.66$ & $38.90 \pm 8.35$ & $206.98 \pm 44.32$ & $199.24 \pm 45.90$ \\
\hline $\begin{array}{c}\mathrm{ICC} \\
\text { (single) }\end{array}$ & \multicolumn{2}{|c|}{$0.75^{*}$} & \multicolumn{2}{|c|}{$0.89^{*}$} & \multicolumn{2}{|c|}{$0.94 *$} \\
\hline $\begin{array}{c}\text { ICC } \\
\text { (average) }\end{array}$ & \multicolumn{2}{|c|}{$0.86^{*}$} & \multicolumn{2}{|c|}{$0.94^{*}$} & \multicolumn{2}{|c|}{$0.97 *$} \\
\hline
\end{tabular}

Note. SD - standard deviation; ICC (single) - reliability of single assessments of intraclass correlation coefficient; (average) - reliability of assessment averages of intraclass correlation coefficient; ${ }^{*}-\mathrm{p}<0.0001$. 
average assessments (significant at $\mathrm{p}<0.0001$ ) (Table 2). Variation coefficient (3.05\%) disclosed a high stability between test results.

The results of the reliability of ICC single assessments and ICC assessment averages of testing the search for image samples revealed a high reliability of the test (significant at $\mathrm{p}<0.0001$ ) (Table 2). Variation coefficient (2.68\%) disclosed a very high stability between test results.

The results of assessing the reliability of $I C C$ single assessments and ICC average assessments of testing attention transfer revealed a very high reliability of the test (significant at $\mathrm{p}<0.0001$ ) (Table 2). Variation coefficient (3.74\%) disclosed a high stability between test results.

\section{DISCUSSION}

There are no standardized tests to assess cognitive functions in Lithuania. This research aims at the assessment of the reliability of attention and memory tests. The chosen collection of tests is meant for the assessment of such cognitive functions as attention and memory. The assessment of attention helps to explore the main characteristics of attention: stability, concentration, distribution and transfer (Martens et al., 2010). Memory tests are used to assess the stages of short-term memory: memorization, storage and recall. Re-testing has been organized to determine the reliability of tests (test-re-test), which include two cases of observing the same participant in two different periods. The tests are referred to as reliable, since similar results have been obtained in both cases. Reliability assessment can be attributed to objective methods of assessment, as methods of statistical calculation have been strictly observed (Friedman et al., 2008). Two coefficients, namely intraclass correlation coefficient (ICC) and coefficient of variation (CV), have been selected to assess the reliability of tests.

The volume of spatial memory has been assessed in accordance with the theory of H. Y. Eng, D. Chen and Y. Yang (2005), who state that the intervals of $5000 \mathrm{~ms}$ or even shorter can be applied for the testing of sensory memory. The duration of the appearance of objects (in our case numeric sequences) on the monitor is very important in this type of tests. According to the afore-mentioned authors, $3000 \mathrm{~ms}$ is the average time span to assess the volume of visual working memory accomplishing such or similar tasks. Using the functional magnetic resonance imaging (fMRI), J. H. Song and Y. Yang (2006) determined that parietal, frontal and parietal-temporal lobes are responsible for the visual working memory.

The assessment of the memory of even numbers recognition is based on structuring, i.e. coding of information in larger units, which enhance the quantity of the processed information. The grouping of numbers is effective in enhancing the volume of short-term memory, and we employ this either consciously or unconsciously (Palmgren, 2010). The structuring is possible provided the information, which is stored in long-term memory, is activated (e. g. the number 10 is the month of birth, etc.). It has been determined that the coding of information is especially dependent on the capacity of working (operational) memory (Skurvydas, 2011). The part of brain, which is responsible for working memory, is hyppocampus, whereas parietal lobe, which is in the back part of the brain, is responsible for information recall (Thoresen et al., 2011).

The results of testing the volume of our spatial memory and memory for even number recognition, in accordance with intraclass correlation coefficient (ICC single, ICC average), show a high or very high correlation of the results of both tests (the test and re-test).

The occipital lobe of the brain is responsible for the recognition of spatial figures (Palmgren, 2010). M. C. Jackson and J. E. Raymond (2008) have determined that the pictures, which present recognizable objects, are better memorized rather than those, which depict abstract motifs. The results of the reliability of single assessment (ICC single) of our testing the memory for figure recognition have demonstrated low reliability, whereas the results of the reliability of assessment averages (ICC average) have shown average reliability. It is credible that the complexity of the test has determined the average and low reiteration of test results. A. Skurvydas (2011) maintain that concentration of attention on two or more objects almost always results in worse accomplishment of tasks.

Selection of important information is performed with the help of visual attention. The dorso-lateral pre-frontal lobe of cerebral cortex is important in the accomplishment of the test of assessing a complex reaction. It is the controlling center, which supervises information loads obtained by senses, and controls the areas, which need attention. Another important part is temporal lobe, which is responsible for attention (Kastner et al., 1999). Pre-frontal lobes are responsible for the results of testing the search for image samples, 
which control alertness, and regulate the states of attention and activeness. The frontal lobe is highly important in testing attention transfer, which determines concentration of attention, integrates the awareness and understanding of all the components of information, as well as organizes the processing of information data (Chein, Fiez, 2010). After having summarized the indicators of the reliability of attention tests, and referring to intraclass correlation coefficient (ICC single, ICC average), it occurred that all the accomplished tests show a high or a very high stability of the results of both tests (the test and re-test).

The indicators of variation coefficients obtained from all tests, both attention and memory, are lower than 5\%, which shows a high stability between the test and re-test results with a minimum variation.

\section{CONCLUSIONS AND PERSPECTIVES}

The reliability of the tests of memory and attention assessment is high (with the exception of figure recognition tests, whose reliability is average/low); therefore, the tests are suitable to be used in sport and clinical rehabilitation practice, aiming at determining the changes in cognitive functions under the influence of external factors, e. g. cold, heat, etc.

\section{REFERENCES}

Aarrestad, D. D., Williams, M. D., Fehrer, S. C., Mikhailenok, E., Leonard, C. T. (2004). Intra- and interrater reliabilities of the myotonometer when assessing the spastic condition of children with cerebral palsy. Journal of Child Neurology, 11 (19), 894-901.

Axmacher, N., Elger, C. E., Fell, J. (2009). Working memory-related hippocampal deactivation interferes with long-term memory formation. The Journal of Neuroscience, 29 (4), 1052-1060.

Chein, J. M., Fiez, J. A. (2010). Evaluating models of working memory through the effects of concurrent irrelevant information. Journal Experimental Psychology General, 139 (1), 117-137.

Collie, A., Maruff, P., Makdissi, M. et al. (2003). CogSport: Reliability and correlation with conventional cognitive tests used in postconcussion medical evaluations. Clinical Journal of Sport Medicine, 13 (1), 28-32.

Correani, A., Humphreys, G. W. (2011). An impaired attentional dwell time after parietal and frontal lesions related to impaired selective attention not unilateral neglect. Cognitive Neuropsychology, 28 (5), 363-385.

Ebbinghaus, H. (1885/1962). Memory: A Contribution to Experimental Psychology. New York: Dover.

Eng, H. Y., Chen, D., Yiang, Y. (2005). Visual working memory for simple and complex visual stimuli. Psychonomic Bulletin \& Review, 12 (6), 1127-1133.

Friedman, L., Stern, H., Brown, G. G. et al. (2008). Testretest and between-site reliability in a multicenter fMRI study. Human Brain Mapping, 29 (8), 958-972.

Gur, R. C., Richard, J., Hughett, P. et al. (2010). A cognitive neuroscience-based computerized battery for efficient measurement of individual differences: Standardization and initial construct validation. Journal Neuroscience Methods, 187 (2), 254-262.

Jackson, M. C., Raymond, J. E. (2008). Familiarity enhances visual working memory for faces. Journal of Experimental Psychology: Human Perception \& Performance, 34 (3), 556.

Kastner, S., Pinsk, M. A., Weerd, P. D., Desimone, R., Ungerleider, L. G. (1999). Increased activity in human visual cortex during directed attention in the absence of visual stimulation. Neuron, 22, 751-761.

Kramer, P., Bressan, P., Grassi, M. (2011). Time estimation predicts mathematical intelligence. PLoS One, 6 (12), e 28621.

Kubicki, A., Bonnetblanc, F., Petrement, G., Ballay, Y., Mourey, F. (2012). Delayed postural control during selfgenerated perturbations in the frail older adults. Clinical Interview Aging, 7, 65-75.

Liu, Y., Wang, M., Tynjälä, J. et al. (2010). Test-retest reliability of selected items of Health Behaviour in School-aged Children (HBSC) survey questionnaire in Beijing, China. BMC Medical Research Methodology, 10 (73), doi:10.1186/1471-2288-10-73.

Martens, S., Kandula, M., Duncan, J. (2010). Restricted attentional capacity within but not between sensory modalities: An individual differences approach. PLoS ONE, 5 (12), e 15280.

Miller, G. A. (1955). The magical number seven, plus or minus two some limits on our capacity for processing information. Psychological Review, 2 (101), 343-352.

Min, B. K. (2010). A thalamic reticular networking model of consciousness. Theoretical Biology and Medical Modelling, 7 (30), 10.

Mizuno, T., Takeda, K. (2009). The symptomatology of frontal and temporal lobe damages. Brain Nerve, 61 (11), 1209-1218.

Morey, C. C., Cowan, N. (2005). Learning, memory, and cognition. Journal of Experimental Psychology, 31 (4), 703-713.

Palmgren, G. (2010). Smegenu paslaptys: kaip veikia atmintis. Iliustruotasis mokslas, 10 (37), 34-43. 
Singh, A. S., Vik, F. N., Chinapaw, M. J. et al. (2011). Test-retest reliability and construct validity of the ENERGY-child questionnaire on energy balancerelated behaviours and their potential determinants: the ENERGY-project. International Journal of Behavioral Nutrition and Physical Activity, 8, 136.

Skurvydas, A., Brazaitis, M., Kamandulis, S. (2011). Repeated bout effect is not correlated with intraindividual variability during muscle-damaging exercise. Journal of Strength \& Conditioning Research, 25 (4), 1004-1009.

Skurvydas, A. (2011). Modernioji neuroreabilitacija. Judesiu valdymas ir proto treniruote. Kaunas: Vitae Litra.

Song, J. H., Yiang, Y. (2006). Visual working memory for simple and complex features: An fMRI study. Neuroimage, 30, 963-972.
Stein, J., Luppa, M., Brähler, E. et al. (2010). The assessment of changes in cognitive functioning: Reliable change indices for neuropsychological instruments in the elderly - a systematic review. Dementia Geriatric Cognitive Disorders, 29 (3), 275-286.

Sutton, J. A., Gillin, W. P., Grattan, T. J., Clarke, G. D., Kilminster S. G. (2002). A new laser pain threshold model detects a faster onset of action from a liquid formulation of $1 \mathrm{~g}$ paracetamol than an equivalent tablet formulation. British Journal of Clinical Pharmacology, 53 (1), 43-47.

Thoresen, C., Jensen, J., Sigvartsen, N. P. et al. (2011). Arousal modulates activity in the medial temporal lobe during a short-term relational memory task. Front Human Neuroscience, 5, 177.

\title{
KOGNITYVINIŲ FUNKCIJŲ (DE்MESIO IR ATMINTIES) TESTŲ PATIKIMUMO VERTINIMAS
}

\author{
Vaida Berneckè $\dot{1}^{1,2}$, Nerijus Eimantas ${ }^{2}$, Henrikas Paulauskas ${ }^{2}$, Beata Skaisgirytè ${ }^{2}$, \\ Justas Kudrevičius ${ }^{2}$, Marius Brazaitis ${ }^{2}$ \\ Šiauliu valstybine kolegija ${ }^{1}$, Šiauliai, Lietuva \\ Lietuvos kūno kultūros akademija², Kaunas, Lietuva
}

\section{SANTRAUKA}

Tyrimo pagrindimas ir hipotezé. Klinikineje praktikoje kognityvinių funkcijų vertinimui naudojami specialūs neuropsichologiniai testai dažnai yra sudėtingi, užimantys daug laiko, reikalaujantys specialių žinių, brangūs, todèl kognityvinès funkcijos dažnai lieka nepakankamai įvertintos. Dėl to mūsų pasirinkti ir patikrinti trumpalaikès atminties ir dėmesio vertinimo testai galètų būti sėkmingai taikomi sporto, klinikinèje reabilitacijos praktikoje.

Tikslas - ivvertinti kognityvinių funkcijų (atminties ir dėmesio) testų patikimumą.

Metodai. Testų patikimumas buvo vertintas naudojant intraklasini koreliacijos koeficientą, kuris turi dvi versijas: pavienių vertinimu patikimumo (ICC single); vertinimų vidurkio patikimumo (ICC average) ir variacijos koeficientą $(V C)$. Buvo tiriami jauni sveiki studentai $(\mathrm{n}=41)$, kurių amžius nuo 18 iki 30 metų $(24.6 \pm 2.3 \mathrm{~m}$.). Testus tiriamieji atliko iš viso keturis kartus, t. y. du kartus (darydami vienos valandos pertrauką) pirmą dieną (mokymas) ir du kartus (darydami vienos valandos pertrauka) antrą dieną (testavimas patikimumui nustatyti).

Rezultatai. Erdvinés atminties apimties ir poriniu skaitmenu atpažinimo atminties testų rezultatai parodè didelị ir labai dideli testų patikimumą. Figūru atpažinimo atminties testo (ICC single) rezultatai parodè mažą, o (ICC average) rezultatai - vidutini testo patikimumą. Sudètingos reakcijos vertinimo, vaizdiniu pavyzdžiu paieškos ir dèmesio nukreipimo testų rezultatai parodè didelị ir labai dideli patikimumą.

Aptarimas ir išvados. Dėmesio ir atminties vertinimo testų patikimumas yra aukštas (išskyrus figūrų atpažinimo atminties testo, kurio patikimumas vidutinis/žemas), todèl testai tinkami naudoti sporto, klinikinejje reabilitacijos praktikoje norint nustatyti kognityvinių funkcijų pokyčius organizmą paveikus išoriniams veiksniams, tokiems kaip šaltis, šiluma ir kt.

Raktažodžiai: smegenų funkcijos, pagrịstumas, stabilumas, testavimas. 